\title{
Corticosterone-Sensitive Monoamine Transport in the Rat Dorsomedial Hypothalamus: Potential Role for Organic Cation Transporter 3 in Stress-Induced Modulation of Monoaminergic Neurotransmission
}

\author{
Paul J. Gasser, ${ }^{1}$ Christopher A. Lowry, ${ }^{2}$ and Miles Orchinik ${ }^{1}$ \\ ${ }^{1}$ School of Life Sciences, Arizona State University, Tempe, Arizona 85287-4501, and ${ }^{2}$ Henry Wellcome Laboratories for Integrative Neuroscience and \\ Endocrinology, Department of Clinical Science at South Bristol, University of Bristol, Bristol BS1 3NY, United Kingdom
}

\begin{abstract}
Glucocorticoid hormones act within the brain to alter physiological and behavioral responses to stress-related stimuli. Previous studies indicated that acute stressors can increase serotonin [5-hydroxytryptamine (5-HT)] concentrations in the dorsomedial hypothalamus (DMH), a midline hypothalamic structure involved in the integration of physiological and behavioral responses to stress. The current study tests the hypothesis that rapid, stress-induced accumulation of 5-HT is attributable to the inhibition of 5-HT transport via organic cation transporters (OCTs). OCTs are a family of high-capacity, bidirectional, multispecific transporters of organic cations (including 5 -HT, dopamine, and norepinephrine) only recently described in brain. In peripheral tissues, organic cation transport via some 0CTs is inhibited by corticosterone. We examined the expression and function of OCTs in the periventricular medial hypothalamus of male Sprague Dawley rats using reverse-transcriptase (RT)-PCR, immunohistochemistry, and in vitro transport assays. RT-PCR revealed expression of OCT3 mRNA, but not OCT1 or OCT2 mRNA, in the medial hypothalamus. OCT3-like immunoreactivity was observed in ependymal and glial-like cells in the DMH. Acutely prepared minces of rat medial hypothalamic tissue accumulated the OCT substrates $\left[{ }^{3} \mathrm{H}\right]$-histamine and $\left[{ }^{3} \mathrm{H}\right]-\mathrm{N}$-methyl-4-phenylpyridinium $\left(\left[{ }^{3} \mathrm{H}\right]-\mathrm{MPP}^{+}\right)$. Consistent with the pharmacological profile of OCT3, corticosterone, 5-HT, estradiol, and the OCT inhibitor decynium 22 dose-dependently inhibited histamine accumulation. Corticosterone and decynium 22 also inhibited efflux of $\left[{ }^{3} \mathrm{H}\right]-\mathrm{MPP}^{+}$from hypothalamic minces. These data support the hypothesis that corticosteroneinduced inhibition of OCT3 mediates stress-induced accumulation of 5-HT in the DMH and suggest that corticosterone may acutely modulate physiological and behavioral responses to stressors by altering serotonergic neurotransmission in this brain region.
\end{abstract}

Key words: serotonin; corticosterone; stress; monoamine; organic cation transporter; uptake

\section{Introduction}

Glucocorticoid hormones exert profound modulatory influences on a range of physiological and behavioral responses to stress. One mechanism through which glucocorticoids may regulate stress responses is by actions on serotonergic systems. Glucocorticoid hormones alter multiple aspects of serotonergic signaling, including tryptophan transport (Neckers and Sze, 1975; Sze, 1976), 5-HT synthesis and metabolism (Kovacs and Telegdy, 1980; Singh et al., 1990; Clark and Russo, 1997), 5-HT receptor function (Meijer and de Kloet, 1998), and tissue concentrations of 5-HT (Losada, 1988; Summers et al., 2000, 2003; Lowry et al.,

Received Feb. 8, 2006; revised June 6, 2006; accepted July 18, 2006.

This work was supported by National Science Foundation (NSF) Grant IBN0220473 (M.0.) and NSF Grant IRFP0502379 (P.J.G.). C.A.L. is a Wellcome Trust Research Fellow (RCDF 068558/Z/02/Z). This collaboration was also supported by the Leverhulme Trust, which sponsored M.0. as a visiting fellow in the Institute for Advanced Studies at the University of Bristol. We are grateful to Dr. Graham Boorse and Andrew Evans for technical assistance.

Correspondence should be addressed to Paul J. Gasser, Henry Wellcome Laboratories for Integrative Neuroscience and Endocrinology, Department of Clinical Science at South Bristol, University of Bristol, Dorothy Hodgkin Building, Whitson Street, Bristol BS1 3NY, UK. E-mail: paul.gasser@bristol.ac.uk.

DOI:10.1523/JNEUROSCI.0570-06.2006

Copyright $\odot 2006$ Society for Neuroscience $\quad$ 0270-6474/06/268758-09\$15.00/0
2001). However, little is known about the specific sites or cellular mechanisms of glucocorticoid modulation of serotonergic signaling.

Previous studies indicate that the dorsomedial hypothalamus $(\mathrm{DMH})$ is a site where stress and glucocorticoids acutely modulate serotonergic signaling. Within $20-30 \mathrm{~min}$ of exposure to a stressor or injection of corticosterone, concentrations of 5-HT increase in the DMH (Kvetnansky et al., 1977; Losada, 1988; Lowry et al., 2001, 2003). In the DMH of rats and salamanders, increases in 5-HT are positively correlated with increases in dopamine and norepinephrine (Lowry et al., 2001, 2003) suggesting that 5-HT, dopamine, and norepinephrine are coregulated in this region. The rapid effects of corticosterone and the coregulation of 5-HT and other monoamines led us to hypothesize that the effects of stress and glucocorticoids within the DMH are mediated by polyspecific organic cation transporters (OCTs) recently described in brain (Vialou et al., 2004).

The OCTs are a family of multispecific, bidirectional, carriertype permeases (for review, see Koepsell et al., 2003). Based on studies of peripheral tissues, all three OCTs transport 5-HT, dopamine, and norepinephrine (Busch et al., 1996; Grundemann et 
al., 1998; Koepsell et al., 2003) and are acutely inhibited by corticosterone (Wu et al., 1998; Arndt et al., 2001). OCT expression has been detected in neurons and cultured glial cells (Russ et al., 1996; Busch et al., 1998; Vialou et al., 2004), and physiological roles for OCTs in the brain have been suggested (Kristufek et al., 2002; Kitaichi et al., 2003; Vialou et al., 2004). However, the functional properties of OCTs in the brain, including substrate specificity, directionality, and sensitivity to inhibition by corticosterone, have not been studied.

The hypothesis that stress- and corticosterone-induced increases in DMH 5-HT are mediated by inhibition of OCTs is supported by a recent study demonstrating that infusion of the OCT inhibitor decynium 22 (D22) into the medial hypothalamus leads to increases in local extracellular 5-HT concentrations (Feng et al., 2005). The present study further tests the hypothesis by examining expression of OCTs in the medial hypothalamus using reverse-transcriptase (RT)-PCR and immunohistochemistry and by testing the effects of corticosterone and OCT inhibitors on uptake and efflux of radiolabeled substrates in acutely prepared medial hypothalamic explants. Because the DMH is involved in the regulation of physiological and behavioral responses to stress (DiMicco et al., 2002), alterations in serotonergic signaling in this region may have effects on the stress response. Portions of this work have been published previously in abstract form (Gasser et al., 2004, 2005).

\section{Materials and Methods}

Animals and housing conditions. Male Sprague Dawley rats were obtained from Charles River Laboratories (Wilmington, MA) or Harlan (Bicester, UK) and were housed in groups of four animals per cage. Cage litter was changed once per week. Animals were maintained under standard lighting conditions (Arizona State University, $12 \mathrm{~h}$ light/dark cycle, lights on at 6:00 A.M.; University of Bristol, 14/10 h light/dark cycle, lights on at 5:00 A.M.). All procedures were performed in accordance with the National Institutes of Health Guide for the Care and Use of Laboratory Animals, Arizona State University Institutional Animal Care and Use Committee, UK Home Office guidelines, and the UK Animals (Scientific Procedures) Act 1986.

$R T-P C R$. Tissues from the medial hypothalamus and kidney were analyzed for OCT1, OCT2, and OCT3 mRNA expression and for the serotonin reuptake transporter (SERT), norepinephrine transporter (NET), dopamine transporter (DAT), and vesicular monoamine transporter 1 (VMAT1) and VMAT2 mRNA expression using standard techniques. Rats were killed by rapid decapitation. Tissues from the medial hypothalamus and kidney were dissected immediately. Medial hypothalamic tissue immediately surrounding the caudal third ventricle (3V-MH) was dissected as described for the transport assays (see below). After dissection, tissues were placed immediately into RNALater (Ambion, Austin, TX) and stored at $4^{\circ} \mathrm{C}$ until RNA isolation. Total RNA was isolated from individual $3 \mathrm{~V}-\mathrm{MHs}$ and kidneys using the RNAWIZ reagent (Ambion) according to the protocol of the manufacturer. One microgram of the resulting total RNA was reverse transcribed for $30 \mathrm{~min}$ at $42^{\circ} \mathrm{C}$ in the presence and absence of engineered Moloney murine leukemia virus $\mathrm{RNase} \mathrm{H}+$ reverse transcriptase (iScript; Bio-Rad, Hercules, CA) with a combination of oligo (dT) and random primers. Two microliters of the resulting cDNA were used as a template for hot-start PCR using HotMaster Taq polymerase (Eppendorf, Westbury, NY) with the following primers (Kristufek et al., 2002): rOCT1 (forward, $5^{\prime}$-GAT CTT TAT CCC GCA TGA GC-3'; reverse, 5' -TTC TGG GAA TCC TCC AAG TG-3'; nucleotides $1300-1777 ; T_{\text {ann }}=55^{\circ} \mathrm{C}$ ), rOCT2 (forward, $5^{\prime}$-CGT TGG GTA GAA TGG GCA TC-3'; reverse, $5^{\prime}$-GTG AGG TTG GTT TGT GTG GG-3'; nucleotides $1401-1863 ; T_{\text {ann }}=57^{\circ} \mathrm{C}$ ), and rOCT3 (forward, $5^{\prime}$ GCC TTG CAG TGT GCT TCA C- $3^{\prime}$; reverse, $5^{\prime}$-GGA ACC TCA GTG GCT TTG G-3'; nucleotides 2095-2561; $\left.T_{\text {ann }}=52^{\circ} \mathrm{C}\right)$. Hot-start PCR was performed with a thermal cycler (MyCycler; Bio-Rad) in $0.2 \mathrm{ml}$ thin-walled PCR tubes. cDNAs were amplified in a total volume of $50 \mu \mathrm{l}$ containing $1 \mathrm{~mm} 2$ '-deoxynucleoside $5^{\prime}$-triphosphates, $1 \mathrm{U}$ HotMaster TaqDNA polymerase (Eppendorf), and $200 \mathrm{ng}$ sense and antisense primers. The thermal cycling parameters were as follows: $94^{\circ} \mathrm{C}$ for $2 \mathrm{~min}$ followed by 36 cycles of $94^{\circ} \mathrm{C}$ for $30 \mathrm{~s}, T_{\text {ann }}$ for $25 \mathrm{~s}$, and $65^{\circ} \mathrm{C}$ for $45 \mathrm{~s}$. After a final extension at $65^{\circ} \mathrm{C}$ for $4 \mathrm{~min}$, PCR products were separated by electrophoresis in $1.5 \%$ agarose gels stained with ethidium bromide.

For amplification of rat SERT, DAT, NET, VMAT1, and VMAT2 mRNA in medial hypothalamic tissue, hot-start PCR was performed as above, except that cycling parameters differed for the various products as noted below. The following primers were used: rSERT (Inazu et al., 2001) [forward, 5' -GTA CCA CCG AAA CGG GTG CA-3'; reverse, 5' -TGG TGG ATC TGC AGG ACA TG-3'; nucleotides $401-700 ; T_{\text {ann }}=60^{\circ} \mathrm{C}$; cycling parameters: 2 min at $95^{\circ} \mathrm{C} ; 35$ times $\left(45 \mathrm{~s}\right.$ at $95^{\circ} \mathrm{C} ; 45 \mathrm{~s}$ at $60^{\circ} \mathrm{C} ; 30 \mathrm{~s}$ at $72^{\circ} \mathrm{C}$ ); $10 \mathrm{~min}$ at $72^{\circ} \mathrm{C}$ ], rDAT (Takeda et al., 2002) [forward, $5^{\prime}$-TCC CTG ACA AGC TTC TCC-3'; reverse, 5'-GCC AGG ACA ATG CCA AGA-3'; nucleotides $1077-1381 ; T_{\text {ann }}=56^{\circ} \mathrm{C}$; cycling parameters: 2 min at $95^{\circ} \mathrm{C}, 35$ times $\left(1 \mathrm{~min}\right.$ at $95^{\circ} \mathrm{C} ; 2 \mathrm{~min}$ at $56^{\circ} \mathrm{C} ; 4 \mathrm{~min}$ at $\left.\left.72^{\circ} \mathrm{C}\right)\right]$; rNET (Inazu et al., 2003b) [forward, $5^{\prime}$-CAT CAA CTG TGT TAC CAG TTT TAT T-3'; reverse, $5^{\prime}$-AAA CAT GGC CAG AAG AAA GGT ACC-3'; nucleotides $1044-1354 ; T_{\text {ann }}=60^{\circ} \mathrm{C}$; cycling parameters: 2 min at $95^{\circ} \mathrm{C}$, 35 times $\left(1 \mathrm{~min}\right.$ at $95^{\circ} \mathrm{C} ; 2 \mathrm{~min}$ at $60^{\circ} \mathrm{C} ; 4 \mathrm{~min}$ at $\left.\left.72^{\circ} \mathrm{C}\right)\right]$, rVMAT1\&2 (Hayashi et al., 1999) [VMAT1 forward, $5^{\prime}$-AGA CAG CAA CTC TTC TCT GC-3' ${ }^{\prime}$; reverse, $5^{\prime}$-CTA TCC CTT GCA AGC AGT TGT- $3^{\prime}$; nucleotides $426-640 ; T_{\text {ann }}=55^{\circ} \mathrm{C}$; VMAT2 forward, $5^{\prime}$-ACT CTA CGG AAA TCC AGA CC- $3^{\prime}$; reverse, $5^{\prime}$-AAT TCC CTG AAG GGA CCT GG-3'; nucleotides $267-685 ; T_{\text {ann }}=53^{\circ} \mathrm{C}$; cycling parameters: 2 min at $94^{\circ} \mathrm{C} ; 30$ times $\left(30 \mathrm{~s}\right.$ at $94^{\circ} \mathrm{C} ; 30 \mathrm{~s}$ at $T_{\text {ann }} ; 1 \mathrm{~min}$ at $\left.\left.72^{\circ} \mathrm{C}\right)\right]$. PCR products were separated by electrophoresis in $1.5 \%$ agarose gels stained with ethidium bromide.

Immunohistochemistry. For immunolocalization of rat OCT3, we used an affinity-purified antibody raised against an 18-amino acid sequence in the large intracellular loop of rOCT3 [rabbit polyclonal anti-rat OCT3; catalog number UBO5402-06, lot number L5061057; Alpha Diagnostics International (ADI), distributed by Europa Bioproducts Ltd, Cambridge, UK). This antiserum was characterized previously (Lips et al., 2005) in human embryonic kidney 293 (HEK293) cells that were stably transfected with expression vectors containing individual OCT-subtypes from rat (HEK-rOCT1, HEK-rOCT2, HEK-rOCT3). Cells expressing rOCT3, but not cells containing the expression vectors alone, or cells expressing rOCT1 or rOCT2, were stained by the ADI affinity-purified rOCT3 antibody. In the current study, three adult male Sprague Dawley rats (weighing 250-300 g) were deeply anesthetized by intraperitoneal injection of $0.5 \mathrm{ml}$ of Euthatal $(200 \mathrm{mg} / \mathrm{ml}$ sodium pentobarbital; Merial, Harlow, UK). Animals were transcardially perfused with $200 \mathrm{ml}$ of $0.05 \mathrm{M}$ PBS followed by $200 \mathrm{ml}$ of $4 \%$ paraformaldehyde in $0.1 \mathrm{M}$ sodium phosphate buffer $(\mathrm{PB})$ fixative, using a peristaltic pump at a flow rate of 31.5 $\mathrm{ml} / \mathrm{min}$. Brains were dissected and postfixed overnight in the same fixative at $4^{\circ} \mathrm{C}$. Brains were then washed in $0.1 \mathrm{M} \mathrm{PB}$ for $24 \mathrm{~h}$ at $4^{\circ} \mathrm{C}$. The solution was changed every $12 \mathrm{~h}$ over this period. The brains were then cryopreserved in $30 \%$ sucrose in $0.1 \mathrm{M} \mathrm{PB}$ for $\sim 72 \mathrm{~h}$. Brains were then blocked at the caudal border of the mammillary bodies (approximately $-5.30 \mathrm{~mm}$ bregma) into two pieces using a rat brain matrix (RBM4000C; ASI Instruments, Warren, MI) and rapidly frozen in dry icechilled liquid isopentane. Brains were stored at $-80^{\circ} \mathrm{C}$ until sectioning. Sections $(25 \mu \mathrm{m})$ were cut across the coronal plane using a cryostat and stored in cryoprotectant [ $30 \%$ ethylene glycol $(\mathrm{w} / \mathrm{w}) / 20 \%$ glycerol $(\mathrm{w} / \mathrm{w})$ in $0.05 \mathrm{M} \mathrm{PB}, \mathrm{pH} 7.4]$ at $-20^{\circ} \mathrm{C}$ until immunostaining. Immunohistochemistry was performed to determine the distribution of OCT3 in the medial hypothalamus. Free-floating sections were incubated in 24-well tissue culture plates and gently shaken on an orbital shaker throughout immunostaining. Sections were first rinsed in $0.05 \mathrm{M}$ PBS for $15 \mathrm{~min}$, treated with $1 \%$ hydrogen peroxide in $0.05 \mathrm{M}$ PBS for $15 \mathrm{~min}$, washed again for $15 \mathrm{~min}$ in PBS, preincubated in PBS containing 0.3\% Triton $\mathrm{X}-100$ (PBST), and then incubated for $16-40 \mathrm{~h}$ at room temperature with primary antiserum diluted $1: 50(0.02 \mu \mathrm{g} / \mu \mathrm{l})$ in $0.1 \%$ PBST. Sections were again rinsed twice for $15 \mathrm{~min}$ in $0.3 \%$ PBST, after which they were incubated for 90 min with secondary antibody (biotinylated swine antirabbit IgG; catalog number E0353; DAKO, Ely, UK) diluted 1:200 in $0.1 \%$ PBST. Sections were rinsed twice in $0.3 \%$ PBST for $15 \mathrm{~min}$, fol- 
lowed by incubation for 90 min with Elite ABC reagent (Vector Laboratories, Peterborough, UK) diluted 1:200 in PBST 30 min before use. Finally, sections were rinsed for $15 \mathrm{~min}$ in $0.3 \%$ PBST, $15 \mathrm{~min}$ in PBS, and incubated in a solution containing $0.001 \% 3,3^{\prime}$-diaminobenzidine tetrahydrochloride and $0.0015 \%$ hydrogen peroxide in PBS for $1-2 \mathrm{~h}$. Stained sections were rinsed for $15 \mathrm{~min}$ in PBS and mounted onto Superfrost slides (VWR, Poole, UK). Sections were coverslipped with 50\% glycerol/ $50 \% 0.1 \mathrm{M}$ PB to obtain wet mount images of ependymal cells lining the third ventricle. Coverslips and sections were then removed. Sections were rinsed in $0.05 \mathrm{M}$ PBS, flash rinsed in distilled water, remounted onto Superfrost slides, and left to dry at room temperature overnight. Sections were then dehydrated in ascending alcohol concentrations and slides were mounted with coverslips using DPX (dibutyl phthalate in xylene) mounting medium (VWR).

As a control for the specificity of the OCT3 immunostaining, one set of tissue sections was incubated with an aliquot of primary antibody that had been incubated overnight at $4^{\circ} \mathrm{C}$ with OCT3 control peptide $(0.2$ $\mu \mathrm{g} / \mu \mathrm{l}$; category number UBO5402-05, lot number L5021803; Europa Bioproducts Ltd).

Images were captured using a Leica (Nussloch, Germany) light microscope fitted with an Insight digital camera (Leica) and SPOT image capture software v4.0.2 (Diagnostic Instruments, Sterling Heights, MI). Cell sizes were estimated using a measurement utility in the SPOT image capture software.

Transport assays. Uptake of 1-[ $\left.{ }^{3} \mathrm{H}\right]$-methyl-4-phenylpyridinium $\left(\left[{ }^{3} \mathrm{H}\right]-\mathrm{MPP}^{+}\right)$and $\left[{ }^{3} \mathrm{H}\right]$-histamine and efflux of $\left[{ }^{3} \mathrm{H}\right]-\mathrm{MPP}^{+}$were measured in acutely prepared minces of periventricular medial hypothalamic tissue. Rats were killed by rapid decapitation by 9:00 on the morning of experiments. Brains were immediately removed and placed into ice-cold artificial CSF (aCSF) (in mm: $118 \mathrm{NaCl}, 3 \mathrm{KCl}, 0.7 \mathrm{Na}_{3} \mathrm{PO}_{4}, 18 \mathrm{NaHCO}_{3}$, 2 urea, $0.8 \mathrm{MgCl}_{2}, 1.4 \mathrm{CaCl}_{2}, 10$ HEPES, and 12 glucose, $\mathrm{pH} 7.6$ ) previously gassed with $95 \% \mathrm{O}_{2} / 5 \% \mathrm{CO}_{2}$. A section of the medial hypothalamus immediately adjacent to the third ventricle extending rostrocaudally from just caudal to the anterior hypothalamic nucleus $(\mathrm{AH})(-2.30 \mathrm{~mm}$ bregma) (Paxinos and Watson, 1998) to the posterior nucleus of the hypothalamus $(\mathrm{PH})(-3.60 \mathrm{~mm}$ bregma), and dorsoventrally from $\sim 0.5$ $\mathrm{mm}$ above the dorsal tip of the third ventricle to the ventral surface of the brain (Fig. 1) was dissected from each brain and placed into fresh, icecold aCSF. This section, termed the $3 \mathrm{~V}-\mathrm{MH}$, contained tissue from the $\mathrm{DMH}$, including the dorsal hypothalamic area (DA), dorsomedial hypothalamic nucleus (DMN), the periventricular hypothalamic nucleus $(\mathrm{Pe})$, the arcuate nucleus (Arc), and small portions of the $\mathrm{PH}$, the ventromedial hypothalamic nucleus $(\mathrm{VMH})$, and the median eminence. Microdissected 3V-MH tissue (from two to four rats per experiment) was chopped into cubes of approximately uniform size using a McIlwain TissueChopper. The pooled cubes were rinsed three times by incubation in 5-6 $\mathrm{ml}$ fresh ice-cold aCSF for $5 \mathrm{~min}$ with gentle agitation. Cubes were separated into aliquots in $1.5 \mathrm{ml}$ microcentrifuge tubes in $350-400 \mu \mathrm{l}$ of fresh aCSF for treatments. In studies testing the effects of 5-HT on OCTmediated transport, aCSF contained $10 \mu \mathrm{M}$ pargyline and $1 \mu \mathrm{M}$ ascorbic acid. Before uptake measurements, tissue was incubated for $10 \mathrm{~min}$ at room temperature, followed by $5 \mathrm{~min}$ at $37^{\circ} \mathrm{C}$. During all transport studies, tissue was incubated at $37^{\circ} \mathrm{C}$ and continually mixed by gentle inversion.

Transport assays. $\mathrm{MPP}^{+}$was initially chosen for transport studies for several reasons: (1) the three OCT isoforms have virtually identical affinities for $\mathrm{MPP}^{+}$(Russ et al., 1992; Grundemann et al., 1994; Martel et al., 1996; Grundemann et al., 1999); (2) $\mathrm{MPP}^{+}$is not subject to cellular metabolism (Sayre, 1989); and (3) the majority of studies characterizing OCT-mediated transport in cell lines used $\mathrm{MPP}^{+}$as substrate. However, in brain, $\mathrm{MPP}^{+}$is also transported by SERT, DAT, NET, and VMATs (Grundemann et al., 1999). Therefore, although MPP ${ }^{+}$has been used effectively to characterize OCT activity in cultured cells expressing individual OCTs in the absence of other transporters, it is not an ideal substrate for measurement of OCT-mediated transport in brain tissue explants. Using brain minces, $\mathrm{MPP}^{+}$uptake mediated by the high-affinity monoamine transporters probably masked OCT-mediated uptake. For this reason, we used two additional measures to more specifically characterize OCT-mediated transport in acutely dissected brain tissues. First,
A
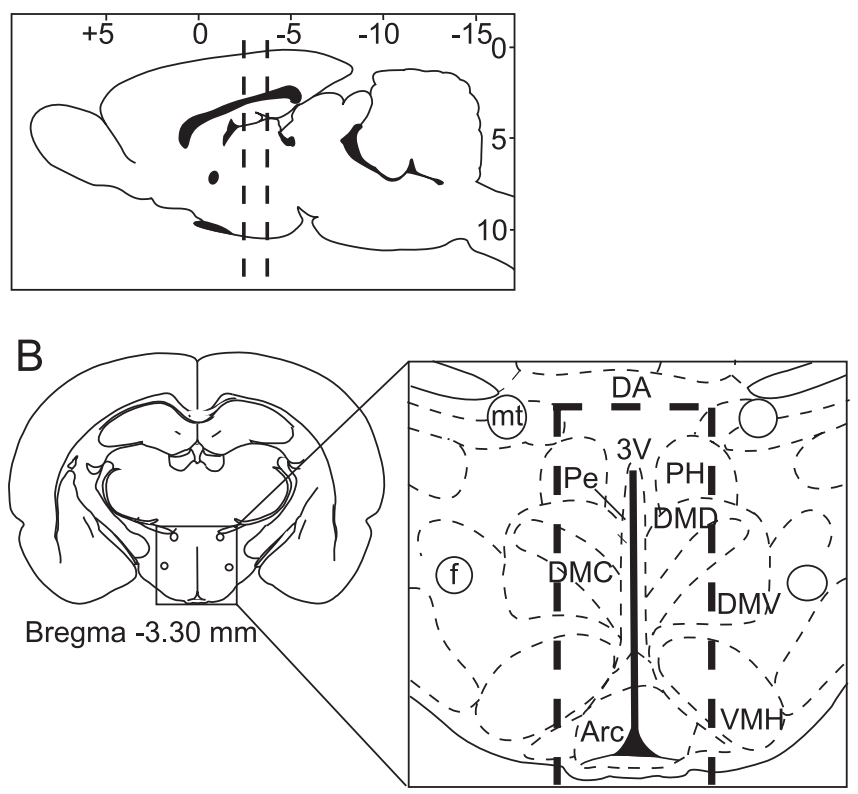

Figure 1. Diagrammatic illustrations indicating the area dissected for RNA extractions and transport assays. Coronal slices were cut at locations indicated by dashed lines in $\boldsymbol{A}$. Slices extended rostrocaudally from approximately -2.30 bregma to -3.60 bregma. The caudal surface of most slices appeared as shown in $\boldsymbol{B}$, with the mammillothalamic tracts appearing just above the dorsal tip of the third ventricle. In the inset $(\boldsymbol{B})$, the dashed lines indicate the periventricular region of hypothalamic tissue (3V-MH) dissected and used for RNA extractions and transport assays. f, Fornix; mt, mammillothalamic tract.

uptake of $\left[{ }^{3} \mathrm{H}\right]$-histamine by $3 \mathrm{~V}-\mathrm{MH}$ minces: of the above-mentioned transporters, only OCT2, OCT3, and VMAT2 are known to transport histamine (Merickel and Edwards, 1995; Dimaline and Struthers, 1996; Grundemann et al., 1999). Second, efflux of $\left[{ }^{3} \mathrm{H}\right]-\mathrm{MPP}^{+}$from preloaded hypothalamic minces: although SERT, DAT, and NET are capable of transporting $\mathrm{MPP}^{+}$, they are all predominantly unidirectional uptake transporters under physiological conditions (Levi and Raiteri, 1993; Scholze et al., 2002; Reed et al., 2003), whereas the OCTs are truly bidirectional transporters (Jonker and Schinkel, 2004).

Uptake studies. The final incubation volume for all uptake studies was $500 \mu \mathrm{l}$. Uptake was initiated by addition of radiolabeled substrates from a concentrated stock (final concentrations: $\left[{ }^{3} \mathrm{H}\right]$ histamine, $200 \mathrm{~nm} ;\left[{ }^{3} \mathrm{H}\right]$ $\mathrm{MPP}^{+}, 25 \mathrm{~nm}\left[{ }^{3} \mathrm{H}\right] \mathrm{MPP}^{+}$or $2 \mathrm{~nm}\left[{ }^{3} \mathrm{H}\right]-\mathrm{MPP}^{+}$plus $1 \mu \mathrm{M}$ unlabeled $\left.\mathrm{MPP}^{+}\right)$. Nonspecific uptake was determined by measuring accumulation of radiolabel in tissue incubated on ice. In studies examining the effects of specific inhibitors on uptake, tissue was incubated in the presence or absence of inhibitors for $10 \mathrm{~min}$ before addition of radiolabeled substrates. Uptake was terminated after 2 min (except for time course studies, and unless otherwise noted) in the following manner: tissue was pelleted by brief centrifugation; aCSF was removed (and reserved); tissue was rinsed three times with $1 \mathrm{ml}$ of ice-cold aCSF, resuspended in $0.5 \mathrm{ml}$ of $1 \mathrm{~N} \mathrm{NaOH}$, and dissolved by incubation at $150^{\circ} \mathrm{C}$ for $15 \mathrm{~min}$. Radioactivity in tissue and aCSF was determined by liquid scintillation spectroscopy. Protein concentration in each tissue sample was determined by a modification of the Bradford protein assay (Bradford, 1976). Uptake experiments were repeated at least three times, except where noted.

Efflux studies. Tissue was loaded with $\left[{ }^{3} \mathrm{H}\right]-\mathrm{MPP}^{+}$by incubation with $25 \mathrm{nM}\left[{ }^{3} \mathrm{H}\right] \mathrm{MPP}^{+}$in $1 \mathrm{ml}$ of aCSF for $1 \mathrm{~h}$ at $37^{\circ} \mathrm{C}$ with continual inversion mixing. Tissue was then rinsed twice with $1 \mathrm{ml}$ of ice-cold aCSF. Efflux was initiated by addition of $1 \mathrm{ml}$ of fresh aCSF at $37^{\circ} \mathrm{C}$ and measured at $5 \mathrm{~min}$ intervals during a $45 \mathrm{~min}$ incubation period. Samples $(500 \mu \mathrm{l})$ of aCSF were taken every $5 \mathrm{~min}$ and replaced with $500 \mu \mathrm{l}$ of fresh, warm aCSF. In studies examining the effects of inhibitors on efflux, inhibitors or vehicle were added from $2 \times$ concentrated stocks after three samples had been taken in the absence of inhibitors. Samples taken after inhibitors were added were replaced with aCSF containing inhibitor or 
A
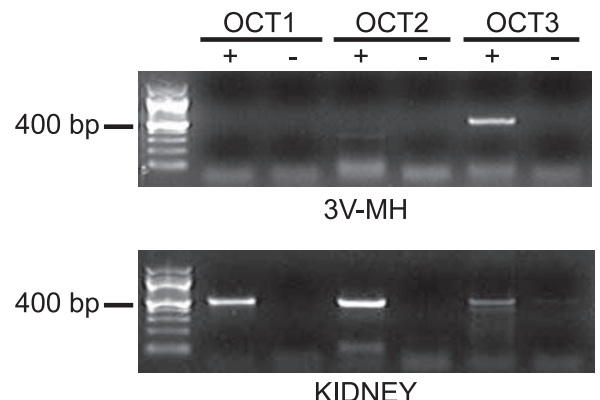

B
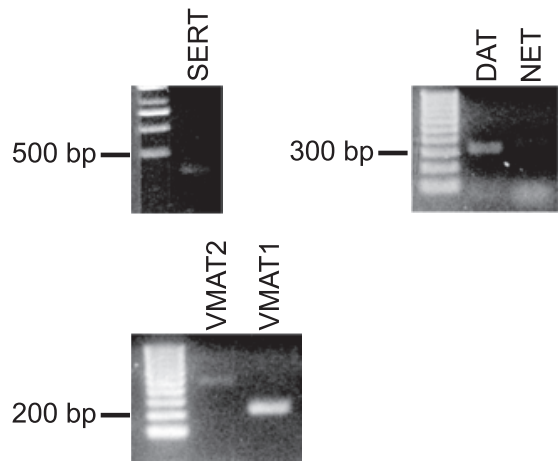

Figure 2. Expression of mRNA for organic cation transporters 1-3 and other monoamine transporters. A, RT-PCR was performed using total RNA extracted from 3V-MH or kidney and primers specific to rat $0 C T s$, 2 , or 3. PCR was performed on CDNA samples generated in the presence $(+)$ or absence $(-)$ of reverse transcriptase. The sizes and positions of relevant markers are noted on the left. Only RT-PCR that included reverse transcriptase $(+)$ produced distinct bands for any of the OCTs. mRNAs for OCT 1, 2, and 3 were detected in the kidney, whereas only OCT3 mRNA was detected in 3V-MH. $\boldsymbol{B}, \mathrm{PCR}$ was performed with CDNA from 3V-MH tissue and primers specific to rat SERT, DAT, NET, VMAT1, and VMAT2. mRNAs for each of these transporters were detected in 3V-MH.

vehicle. Transport was terminated as described above. Fractional efflux, the amount of radioactivity released per 5 min fraction $(500 \mu \mathrm{l})$, was expressed as disintegrations per minute per microgram of protein.

Data analysis. Results are expressed as means \pm SD from independent replicate experiments. All data were analyzed using GraphPad Prism version 4.00 (GraphPad Software, San Diego, CA). Transport data were analyzed by fitting untransformed data to appropriate equations using iterative, least-squares curve-fitting techniques. Early kinetic parameters were determined by fitting accumulation-time data to the first order rate equation using Prism software. $\mathrm{IC}_{50}$ values for inhibitors were determined by fitting the pooled data from independent experiments to the one-site competition equation using nonlinear regression.

\section{Results \\ Characterization of monoamine transporter expression in periventricular $\mathrm{DMH}$ region}

RT-PCR was used to analyze expression of OCTs 1, 2, and 3 as well as several other monoamine transporters in the rat $3 \mathrm{~V}-\mathrm{MH}$. PCR was performed on mRNA samples generated in the presence or absence of reverse transcriptase. Rat kidney tissue was analyzed as a positive control for OCT1, OCT2, and OCT3 expression (Jonker and Schinkel, 2004). mRNAs for OCT1, OCT2, and OCT3 were detected in the rat kidney, whereas only OCT3 mRNA was clearly detected in 3V-MH (Fig. 2A). mRNA for SERT, DAT, NET, VMAT1, and VMAT2 was also detected in 3V-MH (Fig. 2 B).

\section{Distribution of OCT3 in dorsomedial hypothalamus and other areas}

Immunohistochemical methods yielded consistent patterns of OCT3-like immunoreactivity in the DMH region. OCT3-like immunoreactivity was observed in at least two cell types in the DMH region: (1) putative glial cells with cell body diameters ranging from 6 to $10 \mu \mathrm{m}$, with an average diameter of $7.6 \mu \mathrm{m}$ (Fig. 3); and (2) ependymal cells lining the third ventricle (Fig. 3). OCT3-like immunostaining of glial-like and ependymal cells was eliminated by preincubation of the primary antibody with the vendorsupplied blocking peptide (Fig. 3B). OCT3-immunoreactive (OCT3-IR) glial-like cells were densely distributed throughout the DMH, including the DA, dorsomedial hypothalamic nucleus, dorsal part (DMD), and dorsomedial hypothalamic nucleus, ventral part (DMV), and were particularly densely distributed within the dorsomedial hypothalamic nucleus, compact part (DMC) (Fig. 4). In contrast, fewer OCT3-IR glial-like cells were observed in the VMN and Arc (Fig. 4). OCT3-IR ependymal cells were restricted to the dorsal half of the third ventricle (Fig. 4A).

\section{Transport assays}

$\left[{ }^{3} \mathrm{H}\right]-\mathrm{MPP}^{+}$uptake

Acutely prepared minces of medial hypothalamic tissue accumulated $\left[{ }^{3} \mathrm{H}\right]-\mathrm{MPP}^{+}$in a time-dependent manner (Fig. $5 A$ ). Kinetic studies indicated that uptake of $\left[{ }^{3} \mathrm{H}\right]-\mathrm{MPP}^{+}$by hypothalamic cells was inhibited at all time points by D22, an inhibitor of OCT transport activity (Fig. 5A). Nonspecific uptake, determined by incubation at $0^{\circ} \mathrm{C}$, accounted for $10-15 \%$ of total uptake. A onephase exponential association curve was fit to the kinetic data yielding a $k_{\mathrm{obs}}=0.0626$ and $t_{1 / 2}=11.07 \mathrm{~min}$. Maximal uptake at $60 \mathrm{~min}$ was $0.72 \pm 0.06 \mathrm{pmol} / \mathrm{mg}$ protein, and $\sim 65 \%$ of maximal uptake was observed within $20 \mathrm{~min}$. Titration experiments indicated that uptake of $\left[{ }^{3} \mathrm{H}\right]-\mathrm{MPP}^{+}$was partially blocked by D22 and corticosterone (Fig. 5, Table 1). Although the inhibitory effect of corticosterone on $\left[{ }^{3} \mathrm{H}\right]-\mathrm{MPP}^{+}$uptake was small compared with the effect of D22, corticosterone was more potent than D22 (Fig. 5B, Table 1). The SERT inhibitor fluoxetine and the NET inhibitor tomoxetine each inhibited up to $30 \%$ of $\left[{ }^{3} \mathrm{H}\right]-$ $\mathrm{MPP}^{+}$uptake (Fig. 5B, Table 1). When administered in combination, fluoxetine and tomoxetine inhibited up to $65 \%$ of $\left[{ }^{3} \mathrm{H}\right]-$ $\mathrm{MPP}^{+}$uptake (data not shown). Desipramine, which blocks both SERT- and NET-mediated uptake, dose dependently inhibited up to $70 \%$ of $\left[{ }^{3} \mathrm{H}\right]-\mathrm{MPP}^{+}$uptake (Fig. $5 B$, Table 1). GBR12909 [1-(2-[bis(4-fluorophenyl)methoxy] ethyl)-4-(3phenylpropyl)piperazine], a specific inhibitor of the dopamine transporter, had no effect on $\left[{ }^{3} \mathrm{H}\right]-\mathrm{MPP}^{+}$uptake in $3 \mathrm{~V}-\mathrm{MH}$ tissue (Fig. 5B). These data suggest that D22-sensitive uptake of $\left[{ }^{3} \mathrm{H}\right]-\mathrm{MPP}^{+}$occurs through OCTs, SERT, and NET in hypothalamic minces. Therefore, to isolate OCT-mediated uptake from that mediated by SERT and NET, we examined uptake of $\left[{ }^{3} \mathrm{H}\right]$-histamine.

\section{$\left[{ }^{3} \mathrm{H}\right]$-histamine uptake}

Acutely prepared $3 \mathrm{~V}-\mathrm{MH}$ minces accumulated $\left[{ }^{3} \mathrm{H}\right]$-histamine in a time-dependent manner (Fig. 6A). Uptake was best described by a one-phase exponential association curve with $k_{\mathrm{obs}}=$ 0.066 and $t_{1 / 2}=10.48 \mathrm{~min}$. Maximal uptake at $60 \mathrm{~min}$ was 0.82 $\mathrm{fmol} / \mathrm{mg}$ protein, much less than the maximum uptake of $\left[{ }^{3} \mathrm{H}\right]$ $\mathrm{MPP}^{+}$. Uptake was dose-dependently inhibited by corticosterone, estradiol, and D22 (Fig. 6B,C; Table 2). As with $\left[{ }^{3} \mathrm{H}\right]-$ $\mathrm{MPP}^{+}$transport, corticosterone was a more potent inhibitor of $\left[{ }^{3} \mathrm{H}\right]$-histamine uptake than was D22 (Fig. $6 \mathrm{~B}$, Table 2). In contrast to $\left[{ }^{3} \mathrm{H}\right]-\mathrm{MPP}^{+}$, however, corticosterone and D22 inhibited 
a similar fraction of specific $\left[{ }^{3} \mathrm{H}\right]-$ histamine uptake. To determine whether corticosterone and D22 inhibit the same transport process, $\left[{ }^{3} \mathrm{H}\right]$-histamine uptake was measured in tissue minces incubated in aCSF containing increasing concentrations of D22 in the presence or absence of 3 $\mu \mathrm{M}$ corticosterone. There was no additive effect of corticosterone on D22 inhibition of $\left[{ }^{3} \mathrm{H}\right]$-histamine uptake (Fig. $6 C$ ), suggesting that corticosterone and D22 inhibit the same transport process. To determine whether 5-HT was also a substrate for this $\left[{ }^{3} \mathrm{H}\right]$-histamine uptake transporter, minces were incubated with $\left[{ }^{3} \mathrm{H}\right]$ histamine in the presence of increasing concentrations of $5-\mathrm{HT}$. We found that $\left[{ }^{3} \mathrm{H}\right]$-histamine uptake was dosedependently inhibited by 5-HT (Fig. 6D). At concentrations $>1 \mathrm{~mm}, 5-\mathrm{HT}$ inhibited a larger fraction of $\left[{ }^{3} \mathrm{H}\right]$-histamine uptake than did D22.

Whereas all three rat OCTs share certain pharmacological properties, there are key differences in their sensitivities to inhibition by specific competitors and inhibitors. Rat OCT1 is much less sensitive to inhibition by corticosterone $\left(\mathrm{IC}_{50}=150\right.$ $\mu \mathrm{M})$ than are OCT2 $\left(\mathrm{IC}_{50}=0.48-4 \mu \mathrm{M}\right)$ and OCT3 $\left(\mathrm{IC}_{50}=0.3-4.9 \mu \mathrm{M}\right)$ (Wu et al., 1998; Arndt et al., 2001; Shang et al., 2003; Volk et al., 2003). Estradiol $17-\beta$ is a more potent inhibitor of OCT3 $\left(\mathrm{IC}_{50}=1.1 \mu \mathrm{M}\right)$ than of OCT2 $\left(\mathrm{IC}_{50}=85 \mu \mathrm{M}\right)(\mathrm{Wu}$ et al., 1998). Choline inhibits rOCT2-mediated transport with an $\mathrm{IC}_{50}$ value of $159 \mu \mathrm{M}$ (Okuda et al., 1999) but is much less effective at inhibiting OCT3-mediated transport (Wu et al., 1998). To determine the relative contributions of OCT2 and OCT3 to histamine uptake, we tested the effects of estradiol and choline on $\left[{ }^{3} \mathrm{H}\right]$-histamine uptake in $3 \mathrm{~V}$-MH minces. Estradiol inhibited histamine uptake with an $\mathrm{IC}_{50}$ value of $\sim 1.2 \mu \mathrm{M}$ (Fig. $6 B$, Table 2), whereas choline inhibited $\left[{ }^{3} \mathrm{H}\right]$-histamine uptake with an $\mathrm{IC}_{50}$ value of $10.5 \mathrm{~mm}$ (Fig. $6 \mathrm{D}$, Table 2).

$\left[{ }^{3} \mathrm{H}\right]-\mathrm{MPP}{ }^{+}$efflux

Basal rates of $\left[{ }^{3} \mathrm{H}\right]-\mathrm{MPP}^{+}$efflux were low and unaffected by treatment with D22 or corticosterone. Treatment with the VMAT inhibitor reserpine stimulated $\left[{ }^{3} \mathrm{H}\right]-\mathrm{MPP}^{+}$efflux (data not shown). Reserpine-induced efflux was further (dose-dependently) enhanced by treatment with desipramine (Fig. 7A). These data indicated the need to inhibit SERT- and NET-mediated uptake, and VMAT-mediated sequestration, of $\left[{ }^{3} \mathrm{H}\right]-\mathrm{MPP}^{+}$to observe efflux of the substrate. Therefore, in all subsequent studies, basal efflux of $\left[{ }^{3} \mathrm{H}\right]-\mathrm{MPP}^{+}$was measured for $15 \mathrm{~min}$. Reserpine $(30 \mu \mathrm{M})$ and desipramine $(20 \mu \mathrm{M})$ were then added, with or without OCT inhibitors, and efflux was measured for an additional $45 \mathrm{~min}$. Reserpine-/desipramine-stimulated efflux was dose-dependently inhibited by $\mathrm{D} 22$ and corticosterone (Fig. $7 \mathrm{~B}, \mathrm{C}$ ). At the highest doses, both D22 and corticosterone inhibited all reserpine-/ desipramine-stimulated efflux of $\left[{ }^{3} \mathrm{H}\right]-\mathrm{MPP}^{+}$.

\section{Discussion}

We have demonstrated that the organic cation transporter OCT3 is expressed in the rat $\mathrm{DMH}$ and acts as a functional transporter of organic cations, including 5-HT, in the CNS. In addition, we have demonstrated that OCT3-mediated transport in the DMH, like OCT3-mediated transport in peripheral tissues, is bidirectional and inhibited by corticosterone. To our knowledge, this is the first such demonstration of OCT3 transport activity in brain tissue. Together with previous studies (Feng et al., 2005), these data suggest that OCT3 may regulate serotonergic neurotransmission within the $\mathrm{DMH}$ and possibly other brain regions. The sensitivity of OCT3-mediated transport in DMH tissues to inhibition by corticosterone $\left(\mathrm{IC}_{50}=30 \mathrm{nM}\right.$ for histamine, $150 \mathrm{nM}$ for $\mathrm{MPP}^{+}$) suggests that, during stress, corticosterone may alter the rate of postsynaptic clearance (and therefore the extracellular concentrations) of organic cations, including 5-HT, dopamine, histamine, and/or norepinephrine in the DMH. This mechanism may explain previously reported rapid stress- and corticosteroneinduced increases in the concentrations of 5-HT and other monoamines in the DMH of diverse vertebrate species (Lowry et al., 2001, 2003).

The data from RT-PCR and functional assays suggest that OCT3 is the major OCT expressed in the DMH. This is in agreement with data from Amphoux et al. (2006), who recently reported detection of OCT3 mRNA in "periventricular hypothalamus" by in situ hybridization. Although mRNAs for OCT1, OCT2, and OCT3 have been reported previously in human and rat brain (Okuda et al., 1996; Wu et al., 1998; Slitt et al., 2002; Haag et al., 2004), our data indicate that OCT1 and OCT2 are not highly expressed in rat $3 \mathrm{~V}-\mathrm{MH}$ tissue. In addition, the pharmacological properties of rat brain organic cation transport reported 


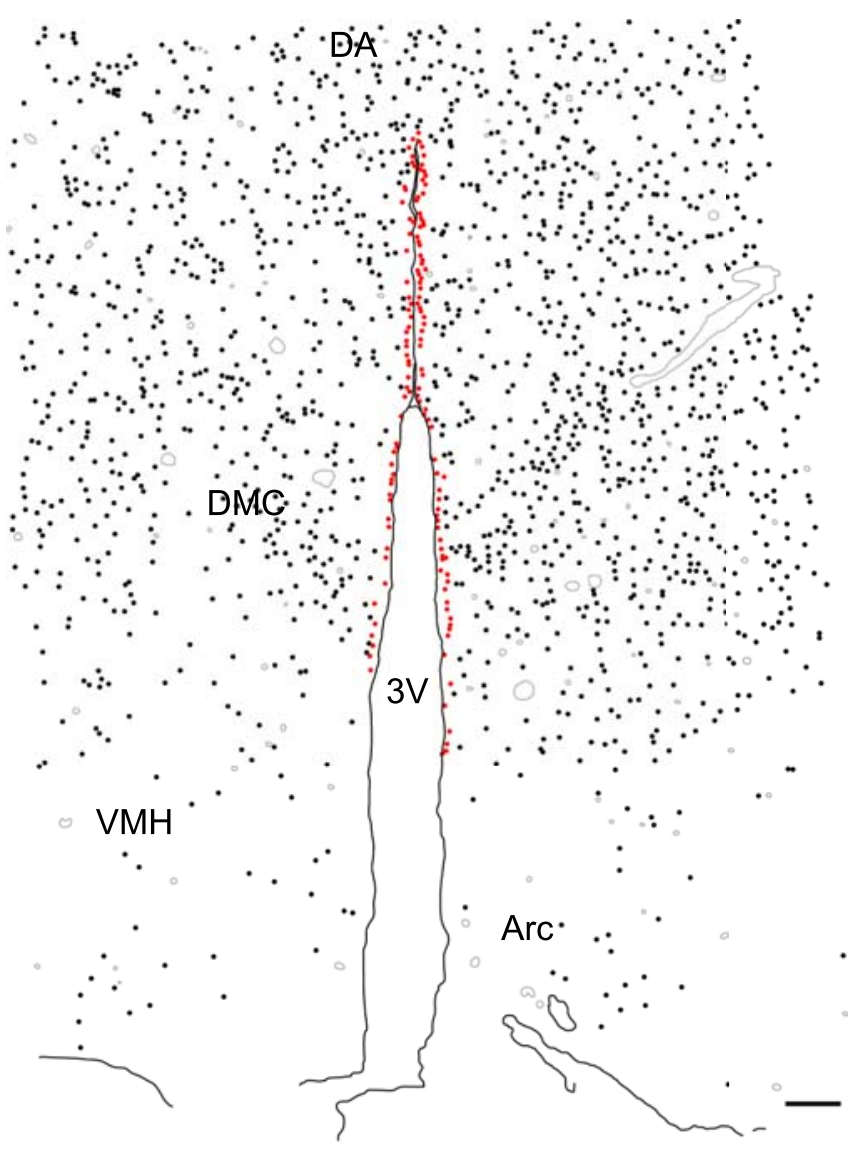

Figure 4. $\quad 0 \mathrm{CT} 3$ is expressed widely throughout the rat DMH. Camera lucida drawing illustrating the distribution of OCT3-IR cells in the DMH. OCT3-IR cells were densely distributed throughout the DMH, including the DA, DMD, DMV, and DMC, but were very sparse in the VMH and Arc. OCT3-IR glial-like cells (black dots) were especially dense within the DMC. OCT3-IR ependymal cells (red dots) were observed only in the top half of the third ventricle. Gray lines indicate blood vessels. Scale bar, $100 \mu \mathrm{m}$.
A

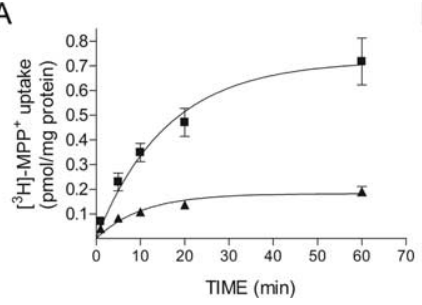

B

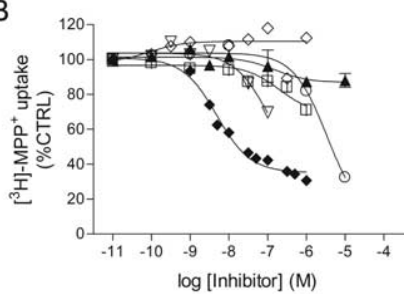

Figure 5. Accumulation of $\left[{ }^{3} \mathrm{H}\right]-\mathrm{MPP}{ }^{+}$in rat medial hypothalamic tissue: sensitivity to inhibitors of OCTs and other transporters. $A, 3 \mathrm{~V}$-MH tissue minces were incubated in aCSF containing $2 \mathrm{~nm}\left[{ }^{3} \mathrm{H}\right]-\mathrm{MPP}^{+}$and $1 \mu \mathrm{m}$ unlabeled MPP ${ }^{+}$, with $(\boldsymbol{\Delta})$ or without $(\boldsymbol{\square}) 30 \mu \mathrm{M}$ D22 for the indicated times. Time-dependent accumulation of $\left[{ }^{3} \mathrm{H}\right]-\mathrm{MPP}{ }^{+}$was inhibited by D22. $\boldsymbol{B}$, Effects of transport inhibitors on $3 \mathrm{~V}-\mathrm{MH}$ uptake of $\left[{ }^{3} \mathrm{H}\right]-\mathrm{MPP}^{+}$. Tissue minces were incubated with the indicated doses of inhibitor, decynium22 $(\bigcirc)$, corticosterone $(\boldsymbol{\Delta})$, fluoxetine $(\square)$, tomoxetine $(\nabla)$, desipramine $(\diamond)$, and GBR12909 $(\diamond)$ for $10 \mathrm{~min}$, followed by the addition of $25 \mathrm{~nm}\left[{ }^{3} \mathrm{H}\right]-\mathrm{MPP}{ }^{+}$. Uptake was terminated after $2 \mathrm{~min}$. Where present, error bars represent \pm SD from two independent experiments. CTRL, Control.

here are similar to those reported for peripheral OCT3 and OCT3 expressed in cell lines but not for OCT2. Specifically, the sensitivity of $\left[{ }^{3} \mathrm{H}\right]$-histamine uptake to inhibition by choline was very low, suggesting little involvement of OCT2 (Okuda et al., 1999), and the $\mathrm{IC}_{50}$ value for estradiol inhibition of $\left[{ }^{3} \mathrm{H}\right]$-histamine uptake in our studies $(1.2 \mu \mathrm{M})$ is very similar to that reported previously for estradiol inhibition of OCT3 (Wu et al., 1998).
Table 1. Inhibition of $\left.{ }^{3} \mathrm{H}\right] \mathrm{MPP}^{+}$uptake in $3 \mathrm{~V}-\mathrm{MH}$ tissue

\begin{tabular}{lcl}
\hline Drug & $\mathrm{IC}_{50}(\mu \mathrm{M})$ & Maximal inhibition (\%) \\
\hline D22 & $3.4 \pm 1.5$ & 80 \\
Corticosterone & $0.152 \pm 0.107$ & 12 \\
Desipramine & $0.0048 \pm 0.00076$ & 70 \\
Fluoxetine & $0.203 \pm 0.15$ & 29 \\
Tomoxetine & $0.098 \pm 0.019$ & 30
\end{tabular}

$\mathrm{IC}_{50}$ values were determined by fitting pooled data from independent experiments to the one-site competition equation using nonlinear regression.
A

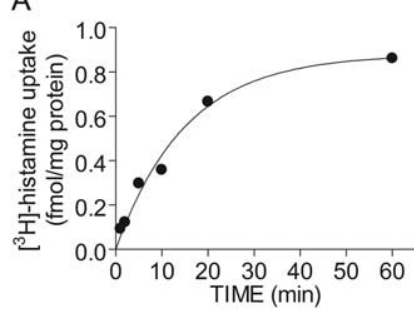

C

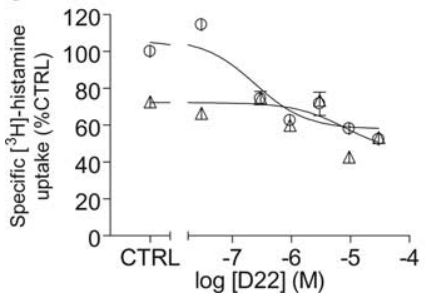

B

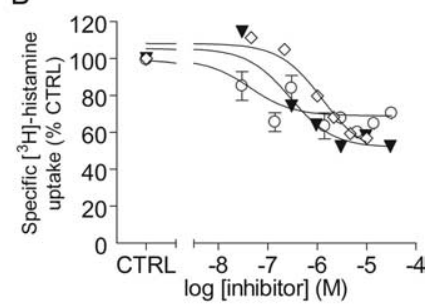

D

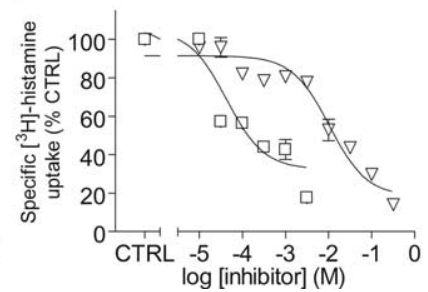

Figure 6. Hypothalamic histamine uptake: sensitivity to OCT inhibitors. $A$, Time-dependent accumulation of $\left[{ }^{3} \mathrm{H}\right]$-histamine. $3 \mathrm{~V}$-MH tissue minces were incubated in aCSF containing 200 nм $\left[{ }^{3} \mathrm{H}\right]$-histamine for the indicated times. $\boldsymbol{B}-\boldsymbol{D}$, Minces of $3 \mathrm{~V}$-MH were incubated in aCSF containing the indicated concentrations of inhibitors for $10 \mathrm{~min}$, after which $200 \mathrm{~nm}\left[{ }^{3} \mathrm{H}\right]$ histamine was added, and uptake was measured for $2 \mathrm{~min} . \mathrm{B}, 3 \mathrm{~V}$-MH accumulation of [ $\left.{ }^{3} \mathrm{H}\right]-$ histamine was dose-dependently inhibited by decynium $22(\boldsymbol{\nabla})$, corticosterone $(\bigcirc)$, and estra$\operatorname{diol}(\diamond)$. Error bars represent \pm SD from two (decynium22) or five (corticosterone) independent experiments. C, Effects of corticosterone preincubation on decynium22-induced inhibition of 3V-MH histamine uptake. Data are means \pm SD from two independent experiments in which $3 \mathrm{~V}$-MH tissue minces were incubated in aCSF containing the indicated concentrations of decynium 22 with $(\triangle)$ and without $(\bigcirc) 3 \mu \mathrm{m}$ corticosterone, after which uptake was measured as above. Decynium22 dose-dependently inhibited [ $\left.{ }^{3} \mathrm{H}\right]$-histamine uptake. Preincubation with $3 \mu \mathrm{m}$ corticosterone alone also inhibited uptake but had no effect on maximal decynium22-induced inhibition of $\left[{ }^{3} \mathrm{H}\right]$-histamine uptake. $\mathrm{D}$, 3V-MH [ $\left.{ }^{3} \mathrm{H}\right]$-histamine uptake was dose-dependently inhibited by $5-\mathrm{HT}(\square)$ and choline $(\nabla)$. Data are means \pm SD from two independent experiments. CTRL, Control.

Table 2. Inhibition of specific $\left[{ }^{3} \mathrm{H}\right]$-histamine uptake in $3 \mathrm{~V}$-MH tissue

\begin{tabular}{lcl}
\hline Drug & $\mathrm{IC}_{50}(\mu \mathrm{M})$ & Maximal inhibition (\%) \\
\hline D22 & $0.28 \pm 0.15$ & 48 \\
Corticosterone & $0.031 \pm 0.018$ & 40 \\
Estradiol & $1.26 \pm 0.68$ & 43 \\
5 -HT & $43 \pm 24$ & 82 \\
Choline & $10500 \pm 3600$ & 86
\end{tabular}

$\mathrm{IC}_{50}$ values were determined by fitting pooled data from independent experiments to the one-site competition equation using nonlinear regression.

We found that corticosterone inhibited the transport of two known OCT substrates in acutely dissected 3V-MH tissues. Corticosterone rapidly inhibited up to $40 \%$ of specific $\left[{ }^{3} \mathrm{H}\right]-$ histamine uptake, equivalent to the inhibition by the OCT inhibitor D22 (Fig. 6). In addition, there was no additive effect of D22 on corticosterone-induced inhibition of histamine uptake. These data suggest that corticosterone and D22 act on the same transporter, within the range of concentrations used. A substantial 
fraction of specific histamine uptake was resistant to inhibition by corticosterone and D22 but was inhibited by choline and 5-HT, suggesting the presence of additional unknown transporters in $3 \mathrm{~V}-\mathrm{MH}$ tissue. Other mediators of DMH histamine uptake may include the newly described plasma membrane monoamine transporter (Engel et al., 2004), which is relatively insensitive to corticosterone $\left(K_{\mathrm{i}}=450 \mu \mathrm{M}\right)$ and the $\mathrm{H} 3$ histamine receptor (Corbel and Dy, 1996).

In contrast to its effect on histamine uptake, corticosterone was less efficacious at inhibiting $\mathrm{MPP}^{+}$uptake than was D22 (Fig. 5B, Table 1). The relative insensitivity of $\left[{ }^{3} \mathrm{H}\right]-\mathrm{MPP}^{+}$uptake to inhibition by corticosterone may be explained by the fact that $\mathrm{MPP}^{+}$is also a substrate for other monoamine transporters, including SERT, NET, and DAT, that are insensitive to corticosterone. The effect of D22 on $\mathrm{MPP}^{+}$uptake may be attributable to reported nonspecific inhibitory effects of high concentrations of D22 on other transporters (Russ et al., 1993). Thus, in our studies, corticosterone-induced inhibition of OCT-mediated $\left[{ }^{3} \mathrm{H}\right]$ $\mathrm{MPP}^{+}$uptake may have been obscured by continued SERT- and NET-mediated uptake. Importantly, both corticosterone and D22 inhibited $100 \%$ of reserpine-/desipramine-stimulated $\mathrm{MPP}^{+}$efflux (Fig. 6), demonstrating the bidirectional nature of corticosterone-sensitive transport in our system, and suggesting that efflux of $\left[{ }^{3} \mathrm{H}\right]-\mathrm{MPP}^{+}$was entirely OCT mediated.

We found OCT3-like immunoreactivity in presumed glial and ependymal cells in the DMH. This agrees with previous reports of OCT3 expression in cultured astrocytes (Russ et al., 1996; Schomig et al., 1998; Inazu et al., 1999, 2003a) and in ependymal cells in rat circumventricular organs (Vialou et al., 2004) and suggests that OCT3 activity in either or both of these cell types may have mediated the effects observed in our functional assays and may play roles in monoamine clearance in the DMH. Glial and ependymal cells also express other mediators of monoamine clearance and metabolism, including SERT (Inazu et al., 2001; Verleysdonk et al., 2004) and monoamine oxidase (MAO) (Ekblom et al., 1993; Verleysdonk et al., 2004). OCT3 colocalizes with MAO-A in the placenta (Verhaagh et al., 2001) and with MAO-B in the area postrema (Haag et al., 2004). Thus, two mechanisms of monoamine clearance may operate in the $\mathrm{DMH}$ : glial-mediated clearance involving uptake followed by MAOmediated metabolism; and ependymal-mediated clearance involving uptake of monoamines from the interstitial fluid, followed by OCT3-mediated efflux into the CSF.

OCT3 expressed in glial and ependymal cells in the DMH may be a stress-sensitive component of the mechanisms regulating monoamine clearance within the DMH. In this model, monoamine clearance under basal conditions would be a combined function of the low-capacity, high-affinity transporters (SERT, NET, and DAT) and the high-capacity, low-affinity transporter OCT3. The contribution of OCT3 to monoamine clearance would increase when local concentrations of monoamines are high enough to saturate other transporters. During stress, when corticosterone levels are elevated, OCT3-mediated monoamine transport by glial and ependymal cells would be inhibited. In combination with increased local serotonergic (or other monoaminergic) neuronal activity, inhibition of OCT3-mediated clearance would in-
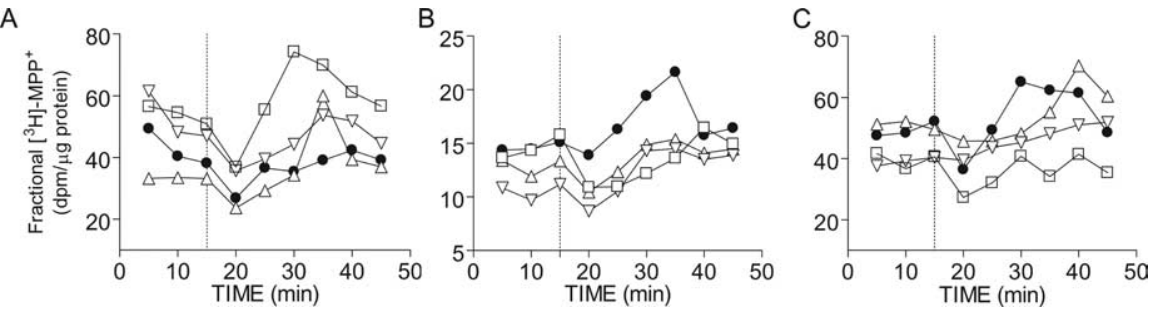

Figure 7. Efflux of $\left[^{3} \mathrm{H}\right]-\mathrm{MPP}{ }^{+}$from $3 \mathrm{~V}-\mathrm{MH}$ minces: sensitivity to transport inhibitors. Minces of $3 \mathrm{~V}-\mathrm{MH}$ were loaded by

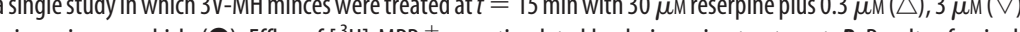
study in which $3 \mathrm{~V}$-MH minces were treated at $t=15$ min with $30 \mu$ reserpine, $20 \mu$ desipramine, and $0.15 \mu \mathrm{M}(\triangle), 1.5 \mu \mathrm{M}$ V), or $15 \mu \mathrm{m}(\square)$ decynium 22, or vehicle (O). C, 3V-MH minces were treated at $t=15$ min with $30 \mu \mathrm{m}$ reserpine, $20 \mu \mathrm{M}$ desipramine plus $100 \mathrm{~nm}(\triangle), 1 \mu \mathrm{M}(\nabla)$, or $10 \mu \mathrm{M}(\square)$ corticosterone, or vehicle $(\circlearrowleft)$. Desipramine stimulation of [ $\left.{ }^{3} \mathrm{H}\right]-\mathrm{MPP}^{+}$ efflux was inhibited by decynium22 (B) and corticosterone ( $\boldsymbol{C}$.

crease local concentrations of 5-HT or other monoamines in the interstitial fluid leading to enhanced 5-HT neurotransmission. This model is supported by studies demonstrating that local application of corticosterone or D22 to the DMH leads to dramatic increases in local extracellular concentrations of 5-HT (Feng et al., 2005; Watt et al., 2005).

The presence of corticosterone-sensitive monoamine transporters in the $\mathrm{DMH}$ may have implications for regulation of physiological and behavioral aspects of the stress response. The $\mathrm{DMH}$ is a key structure for the initiation and regulation of neuroendocrine, autonomic, and behavioral responses to stress (for review, see DiMicco et al., 2002). DMH neurons receive input from key monoaminergic regions of the brain, including the locus ceruleus and the median raphe nucleus (Swanson, 1987; Vertes et al., 1999; Lowry, 2002). Both of these groups of neurons are activated during stress (Abercrombie and Jacobs, 1987; Daugherty et al., 2001) and are proposed to contribute to the regulation of stress responses (Graeff et al., 1996; Deakin, 1998; Shekhar et al., 2002). In previous studies, intracerebroventricular or intrahypothalamic injections of 5-HT agonists either enhanced or inhibited stress-induced increases in plasma corticosterone concentrations depending on dose, location of injection, and the subtype of 5-HT receptor targeted (Vermes and Telegdy, 1972, 1973; Saphier and Welch, 1995; Saphier et al., 1995). Thus, by regulating local 5-HT levels in the $\mathrm{DMH}$, corticosterone regulation of OCTs may contribute to acute regulation of integrated behavioral and physiological responses to stress.

\section{References}

Abercrombie ED, Jacobs BL (1987) Single-unit response of noradrenergic neurons in the locus coeruleus of freely moving cats. I. Acutely presented stressful and nonstressful stimuli. J Neurosci 7:2837-2843.

Amphoux A, Vialou V, Drescher E, Bruss M, La Cour CM, Rochat C, Millan MJ, Giros B, Bonisch H, Gautron S (2006) Differential pharmacological in vitro properties of organic cation transporters and regional distribution in rat brain. Neuropharmacology 50:941-952.

Arndt P, Volk C, Gorboulev V, Budiman T, Popp C, Ulzheimer-Teuber I, Akhoundova A, Koppatz S, Bamberg E, Nagel G, Koepsell H (2001) Interaction of cations, anions, and weak base quinine with rat renal cation transporter rOCT2 compared with rOCT1. Am J Physiol Renal Physiol 281:F454-F468.

Bradford MM (1976) A rapid and sensitive method for the quantitation of microgram quantities of protein utilizing the principle of protein-dye binding. Anal Biochem 72:248-254.

Busch AE, Quester S, Ulzheimer JC, Gorboulev V, Akhoundova A, Waldegger S, Lang F, Koepsell H (1996) Monoamine neurotransmitter transport 
mediated by the polyspecific cation transporter rOCT1. FEBS Lett 395:153-156.

Busch AE, Karbach U, Miska D, Gorboulev V, Akhoundova A, Volk C, Arndt P, Ulzheimer JC, Sonders MS, Baumann C, Waldegger S, Lang F, Koepsell H (1998) Human neurons express the polyspecific cation transporter hOCT2, which translocates monoamine neurotransmitters, amantadine, and memantine. Mol Pharmacol 54:342-352.

Clark MS, Russo AF (1997) Tissue-specific glucocorticoid regulation of tryptophan hydroxylase mRNA levels. Brain Res Mol Brain Res 48:346-354.

Corbel S, Dy M (1996) Evidence for bidirectional histamine transport by murine hematopoietic progenitor cells. FEBS Lett 391:279-281.

Daugherty WP, Corley KC, Phan TH, Boadle-Biber MC (2001) Further studies on the activation of rat median raphe serotonergic neurons by inescapable sound stress. Brain Res 923:103-111.

Deakin JF (1998) The role of serotonin in panic, anxiety and depression. Int Clin Psychopharmacol 13 [Suppl 4]:S1-S5.

Dimaline R, Struthers J (1996) Expression and regulation of a vesicular monoamine transporter in rat stomach: a putative histamine transporter. J Physiol Lond 490:249-256.

DiMicco JA, Samuels BC, Zaretskaia MV, Zaretsky DV (2002) The dorsomedial hypothalamus and the response to stress: part renaissance, part revolution. Pharmacol Biochem Behav 71:469-480.

Ekblom J, Jossan SS, Bergstrom M, Oreland L, Walum E, Aquilonius SM (1993) Monoamine oxidase-B in astrocytes. Glia 8:122-132.

Engel K, Zhou M, Wang J (2004) Identification and characterization of a novel monoamine transporter in the human brain. J Biol Chem 279:50042-50049.

Feng N, Mo B, Johnson PL, Orchinik M, Lowry CA, Renner KJ (2005) Local inhibition of organic cation transporters increases extracellular serotonin in the medial hypothalamus. Brain Res 1063:69-76.

Gasser PJ, Lowry CA, Renner KJ, Orchinik M (2004) Expression and function of organic cation transporters in the rat dorsomedial hypothalamus. Soc Neurosci Abstr 30:1000.9.

Gasser PJ, Lowry CA, Orchinik M (2005) Corticosterone-sensitive monoamine transport in the rat dorsomedial hypothalamus: role for organic cation transporter 3 in stress-induced serotonin accumulation. Soc Neurosci Abstr 31:872.12.

Graeff FG, Guimaraes FS, De Andrade TG, Deakin JF (1996) Role of 5-HT in stress, anxiety, and depression. Pharmacol Biochem Behav 54:129-141.

Grundemann D, Gorboulev V, Gambaryan S, Veyhl M, Koepsell H (1994) Drug excretion mediated by a new prototype of polyspecific transporter. Nature 372:549-552.

Grundemann D, Koster S, Kiefer N, Breidert T, Engelhardt M, Spitzenberger F, Obermuller N, Schomig E (1998) Transport of monoamine transmitters by the organic cation transporter type 2, OCT2. J Biol Chem 273:30915-30920.

Grundemann D, Liebich G, Kiefer N, Koster S, Schomig E (1999) Selective substrates for non-neuronal monoamine transporters. Mol Pharmacol $56: 1-10$.

Haag C, Berkels R, Grundemann D, Lazar A, Taubert D, Schomig E (2004) The localisation of the extraneuronal monoamine transporter (EMT) in rat brain. J Neurochem 88:291-297.

Hayashi M, Haga M, Yatsushiro S, Yamamoto A, Moriyama Y (1999) Vesicular monoamine transporter 1 is responsible for storage of 5-hydroxytryptamine in rat pinealocytes. J Neurochem 73:2538-2545.

Inazu M, Kubota N, Takeda H, Zhang J, Kiuchi Y, Oguchi K, Matsumiya T (1999) Pharmacological characterization of dopamine transport in cultured rat astrocytes. Life Sci 64:2239-2245.

Inazu M, Takeda H, Ikoshi H, Sugisawa M, Uchida Y, Matsumiya T (2001) Pharmacological characterization and visualization of the glial serotonin transporter. Neurochem Int 39:39-49.

Inazu M, Takeda H, Matsumiya T (2003a) Expression and functional characterization of the extraneuronal monoamine transporter in normal human astrocytes. J Neurochem 84:43-52.

Inazu M, Takeda $\mathrm{H}$, Matsumiya $\mathrm{T}$ (2003b) Functional expression of the norepinephrine transporter in cultured rat astrocytes. J Neurochem 84:136-144.

Jonker JW, Schinkel AH (2004) Pharmacological and physiological functions of the polyspecific organic cation transporters: OCT1, 2, and 3 (SLC22A1-3). J Pharmacol Exp Ther 308:2-9.

Kitaichi K, Morishita Y, Doi Y, Ueyama J, Matsushima M, Zhao YL, Takagi K,
Hasegawa T (2003) Increased plasma concentration and brain penetration of methamphetamine in behaviorally sensitized rats. Eur J Pharmacol 464:39-48.

Koepsell H, Schmitt BM, Gorboulev V (2003) Organic cation transporters. Rev Physiol Biochem Pharmacol 150:36-90.

Kovacs GL, Telegdy G (1980) Influence of corticosterone on serotonin metabolism in rat brain. Neurosci Behav Physiol 10:232-236.

Kristufek D, Rudorfer W, Pifl C, Huck S (2002) Organic cation transporter mRNA and function in the rat superior cervical ganglion. J Physiol (Lond) 543:117-134.

Kvetnansky R, Palkovits M, Mitro A, Torda T, Mikulaj L (1977) Catecholamines in individual hypothalamic nuclei of acutely and repeatedly stressed rats. Neuroendocrinology 23:257-267.

Levi G, Raiteri M (1993) Carrier-mediated release of neurotransmitters. Trends Neurosci 16:415-419.

Lips KS, Volk C, Schmitt BM, Pfeil U, Arndt P, Miska D, Ermert L, Kummer W, Koepsell H (2005) Polyspecific cation transporters mediate luminal release of acetylcholine from bronchial epithelium. Am J Respir Cell Mol Biol 33:79-88.

Losada MEO (1988) Corticosterone-induced acute changes on biogenic amines levels in some areas of the rat brain. Biog Amines 5:239-247.

Lowry CA (2002) Functional subsets of serotonergic neurones: implications for control of the hypothalamic-pituitary-adrenal axis. J Neuroendocrinol 14:911-923.

Lowry CA, Burke KA, Renner KJ, Moore FL, Orchinik M (2001) Rapid changes in monoamine levels following administration of corticotropinreleasing factor or corticosterone are localized in the dorsomedial hypothalamus. Horm Behav 39:195-205.

Lowry CA, Plant A, Shanks N, Ingram CD, Lightman SL (2003) Anatomical and functional evidence for a stress-responsive, monoamineaccumulating area in the dorsomedial hypothalamus of adult rat brain. Horm Behav 43:254-262.

Martel F, Martins MJ, Azevedo I (1996) Inward transport of 3H-MPP+ in freshly isolated rat hepatocytes: evidence for interaction with catecholamines. Naunyn Schmiedebergs Arch Pharmacol 354:305-311.

Meijer OC, de Kloet ER (1998) Corticosterone and serotonergic neurotransmission in the hippocampus: functional implications of central corticosteroid receptor diversity. Crit Rev Neurobiol 12:1-20.

Merickel A, Edwards RH (1995) Transport of histamine by vesicular monoamine transporter-2. Neuropharmacology 34:1543-1547.

Neckers L, Sze PY (1975) Regulation of 5-hydroxytryptamine metabolism in mouse brain by adrenal glucocorticoids. Brain Res 93:123-132.

Okuda M, Saito H, Urakami Y, Takano M, Inui K (1996) cDNA cloning and functional expression of a novel rat kidney organic cation transporter, OCT2. Biochem Biophys Res Commun 224:500-507.

Okuda M, Urakami Y, Saito H, Inui K (1999) Molecular mechanisms of organic cation transport in OCT2-expressing Xenopus oocytes. Biochim Biophys Acta 1417:224-231.

Paxinos G, Watson C (1998) The rat brain in stereotaxic coordinates, Ed 4. San Diego: Academic.

Reed B, Chen N, Justice Jr JB (2003) Dual-electrode voltammetry of catecholamine transport: simultaneous monitoring of uptake and efflux. J Neurosci Methods 126:127-135.

Russ H, Gliese M, Sonna J, Schomig E (1992) The extraneuronal transport mechanism for noradrenaline (uptake2) avidly transports 1-methyl-4phenylpyridinium (MPP+). Naunyn Schmiedebergs Arch Pharmacol 346:158-165.

Russ H, Sonna J, Keppler K, Baunach S, Schomig E (1993) Cyanine-related compounds: a novel class of potent inhibitors of extraneuronal noradrenaline transport. Naunyn Schmiedebergs Arch Pharmacol 348:458-465.

Russ H, Staust K, Martel F, Gliese M, Schomig E (1996) The extraneuronal transporter for monoamine transmitters exists in cells derived from human central nervous system glia. Eur J Neurosci 8:1256-1264.

Saphier D, Farrar GE, Welch JE (1995) Differential inhibition of stressinduced adrenocortical responses by 5-HT1A agonists and by 5-HT2 and 5-HT3 antagonists. Psychoneuroendocrinology 20:239-257.

Saphier D, Welch JE (1995) Effects of the serotonin1A agonist, 8-hydroxy2-(di-n-propylamino)tetralin on neurochemical responses to stress. J Neurochem 64:767-776.

Sayre LM (1989) Biochemical mechanism of action of the dopaminergic neurotoxin 1-methyl-4-phenyl-1,2,3,6-tetrahydropyridine (MPTP). Toxicol Lett 48:121-149. 
Scholze P, Norregaard L, Singer EA, Freissmuth M, Gether U, Sitte HH (2002) The role of zinc ions in reverse transport mediated by monoamine transporters. J Biol Chem 277:21505-21513.

Schomig E, Russ H, Staudt K, Martel F, Gliese M, Grundemann D (1998) The extraneuronal monoamine transporter exists in human central nervous system glia. Adv Pharmacol 42:356-359.

Shang T, Uihlein AV, Van Asten J, Kalyanaraman B, Hillard CJ (2003) 1-Methyl-4-phenylpyridinium accumulates in cerebellar granule neurons via organic cation transporter 3. J Neurochem 85:358-367.

Shekhar A, Katner JS, Sajdyk TJ, Kohl RR (2002) Role of norepinephrine in the dorsomedial hypothalamic panic response: an in vivo microdialysis study. Pharmacol Biochem Behav 71:493-500.

Singh VB, Corley KC, Phan TH, Boadle-Biber MC (1990) Increases in the activity of tryptophan hydroxylase from rat cortex and midbrain in response to acute or repeated sound stress are blocked by adrenalectomy and restored by dexamethasone treatment. Brain Res 516:66-76.

Slitt AL, Cherrington NJ, Hartley DP, Leazer TM, Klaassen CD (2002) Tissue distribution and renal developmental changes in rat organic cation transporter mRNA levels. Drug Metab Dispos 30:212-219.

Summers CH, Larson ET, Ronan PJ, Hofmann PM, Emerson AJ, Renner KJ (2000) Serotonergic responses to corticosterone and testosterone in the limbic system. Gen Comp Endocrinol 117:151-159.

Summers TR, Matter JM, McKay JM, Ronan PJ, Larson ET, Renner KJ, Summers CH (2003) Rapid glucocorticoid stimulation and GABAergic inhibition of hippocampal serotonergic response: in vivo dialysis in the lizard anolis carolinensis. Horm Behav 43:245-253.

Swanson LW (1987) The hypothalamus. In: Handbook of Chemical Neuroanatomy (Bjorklund A, Hokfelt T, Swanson LW, eds), pp 1-104. Amsterdam: Elsevier.

Sze PY (1976) Glucocorticoid regulation of the serotonergic system of the brain. Adv Biochem Psychopharmacol 15:251-265.
Takeda H, Inazu M, Matsumiya T (2002) Astroglial dopamine transport is mediated by norepinephrine transporter. Naunyn Schmiedebergs Arch Pharmacol 366:620-623.

Verhaagh S, Barlow DP, Zwart R (2001) The extraneuronal monoamine transporter Slc22a3/Orct3 co-localizes with the Maoa metabolizing enzyme in mouse placenta. Mech Dev 100:127-130.

Verleysdonk S, Hamprecht B, Rapp M, Wellard J (2004) Uptake and metabolism of serotonin by ependymal primary cultures. Neurochem Res 29:1739-1747.

Vermes I, Telegdy G (1972) Effect of intraventricular injection and intrahypothalamic implantation of serotonin on the hypothalamo-hypophysealadrenal system in the rat. Acta Physiol Acad Sci Hung 42:49-59.

Vermes I, Telegdy G (1973) Effect of 5-hydroxytryptamine on stressinduced adrenal function in the guinea pig. Acta Physiol Acad Sci Hung 43:99-103

Vertes RP, Fortin WJ, Crane AM (1999) Projections of the median raphe nucleus in the rat. J Comp Neurol 407:555-582.

Vialou V, Amphoux A, Zwart R, Giros B, Gautron S (2004) Organic cation transporter 3 (Slc22a3) is implicated in salt-intake regulation. J Neurosci 24:2846-2851.

Volk C, Gorboulev V, Budiman T, Nagel G, Koepsell H (2003) Different affinities of inhibitors to the outwardly and inwardly directed substrate binding site of organic cation transporter 2. Mol Pharmacol 64:1037-1047.

Watt MJ, Scholl JL, Feng N, Mo B, Forster GL, Lowry CA, Renner KJ (2005) Synergistic effects of corticosterone and progesterone on serotonin levels in the dorsomedial hypothalamus. Soc Neurosci Abstr 31:186.10.

Wu X, Kekuda R, Huang W, Fei YJ, Leibach FH, Chen J, Conway SJ, Ganapathy V (1998) Identity of the organic cation transporter OCT3 as the extraneuronal monoamine transporter (uptake2) and evidence for the expression of the transporter in the brain. J Biol Chem 273:32776-32786. 